\title{
8.3 Training future doctors of philosophy writing a scientific article
}

Нагадаємо, що відповідно до Постанови Кабінету Міністрів України «Про затвердження Порядку підготовки здобувачів вищої освіти ступеня доктора філософії та доктора наук у закладах вищої освіти (наукових установах) від 23 березня 2016 р. №261 (Постанова ..., 2016) в Україні розпочато підготовку докторів філософії (ДФ). За минулі роки заклади вищої освіти накопичили певний досвід підготовки фахівців цього освітньо-наукового рівня у різних галузях знань, в тому числі галузі освіти 01 Освіта / Педагогіка спеціальності 011 Освітні, педагогічні науки. На жаль, стандарт з цієї галузі знань поки що не розроблено i університети та наукові установи готують ДФ згідно 3 розробленими ними освітньо-науковими програмами (ОНП) та робочими навчальними програмами.

Серед загальних компетентностей, зазначених в цих навчальнометодичних документах, фігурують, наприклад, такі: «Здатність презентувати результати своїх досліджень» або «Здатність готувати наукові статті, тези, доповіді, повідомлення, виступи, наукові звіти, посібники тощо» (Бедзір Н. П., 2017; Перепелиця О. М., 2016). У Київському національному лінгвістичному університеті, на базі якого реалізовано це дослідження, аспірантів готують за ОНП «Сучасні наукові освітні студії: педагогіка, методика навчання іноземних мов і культур, наукова англійська мова» (Ніколаєва С. Ю., 2017). Зазначена ОНП удосконалювалась протягом останніх чотирьох років і в ії крайньому варіанті передбачено викладання навчальної дисципліни «Наукова комунікація: методи оприлюднення результатів дослідження в галузі освіти». Сутність цієї дисципліни схарактеризовано нами у публікації «Структура і зміст дисципліни «Наукова комунікація: методи оприлюднення результатів дослідження в галузі освіти»»» (Ніколаєва С. Ю., 2021).

Навчальною програмою 3 цієї дисципліни серед інших передбачено опрацювання таких тем, як: «Види та жанри наукових публікацій в галузі освіти», «Загальна характеристика наукових публікацій в галузі освіти», але 
моніторинг готовності аспірантів до написання та опублікування наукових статей з проблем їхнього дослідження свідчить про суттєві труднощі, що виникають в аспірантів у цьому виді наукової комунікації. Основні недоліки у написанні статей майбутніми докторами філософії досліджувались протягом багатьох років і узагальнені нами у публікації «Наукова комунікація: труднощі молодих науковців у написанні наукових статей» (Ніколаєва С. Ю., 2021a). Одержані результати дозволяють зробити висновок про необхідність упровадження в освітній процес курсу за вибором, присвяченого саме формуванню в аспірантів здатності писати наукову статтю. До програми курсу насамперед слід внести такі теми: вибір теми наукової статті; основні типи наукових статей; зміст і структура статей різних типів; стратегії написання наукової статті; вимоги до анотації до наукової статті; основні вимоги до статей у фахових виданнях України тощо. Розглянемо детальніше зміст лекцій такого курсу і завдання для самостійної роботи майбутніх докторів філософії в галузі освіти зі спеціальності 011 Освітні, педагогічні науки, спеціалізації «Теорія та методика навчання іноземних мов».

Лекція-бесіда 1. Основні типи публікацій майбутнього ДФ. Загальні вимоги до публікацій ДФ.

Теоретичні питання для розгляду. Основні типи публікацій (автореферат, наукова доповідь, препринт, тези доповіді, стаття наукова, збірник наукових праць, монографія одноосібна, розділ у колективній монографіï). Загальні вимоги до публікацій аспірантів згідно наказу № 1220 МОН України від 23 вересня 2019 року (Наказ МОН..., 2019). Необхідна мінімальна кількість публікацій. Публікації в періодичних наукових виданнях інших держав. Публікації у наукових фахових виданнях України категорій А і Б. Публікації у виданнях, проіндексованих у базах даних Web of Science Core Collection та/або Scopus. Поняття квартилів ((Q 1 - Q 3) відповідно до класифікації SCImago Journal and Country Rank або Journal Citation Reports. Вибір теми першої наукової статті з методики навчання іноземних мов і культур. 
Практичне завдання для виконання в аудиторії. Виберіть тему для Вашої першої наукової статті згідно «Змісту» Вашої дисертації (одного з підрозділів першого розділу). Сформулюйте іiі назву. Врахуйте, що вона має бути короткою, але зрозумілою. Бажано ще й такою, щоб викликала інтерес. Обговорення запропонованих назв статей.

Практичне завдання для самостійного позааудиторного опраџювання.

- Подивіться відеофільм «Робота із профілем автора в інформаційнопошуковій та наукометричній системі Гугл Академія» і визначіть іiі призначення.

Режим доступу: https://www.youtube.com/watch?v=qEsupJNMDD4

- Створіть свій профіль у системі Гугл Академія.

Лекція-бесіда 2. Види наукових статей. Вибір виду першої наукової статті 3 методики навчання іноземних мов і культур для опублікування.

Презентація аспірантами виконаних самостійно практичних завдань. Детальний опис аспірантами можливостей інформаційно-пошукової та наукометричної системи Гугл Академія. Демонстрація створених профілів у цій системі.

Теоретичні питання для розгляду. Загальна характеристика різних видів статей: дослідницької статті, статті-короткого повідомлення, статті-відгуку і відповіді, оглядової статті. Основні вимоги до кожного виду статті. Методична стаття як окремий підвид дослідницької статті. Фактори впливу на вибір виду першої наукової статті з методики навчання іноземних мов і культур. Вимоги до назви статті.

Практичне завдання для самостійного позааудиторного опрацювання.

- Знайдіть у Вісниках КНЛУ Серії «Педагогіка та психологія» за останні п’ять років десять статей з методики навчання іноземних мов і культур різного виду. Проаналізуйте їх зміст і структуру.

Режим доступу: http://visnyk-pedagogy.knlu.edu.ua

- Оберіть вид статті, яку Ви плануєте написати. Поясніть фактори, що зумовили обрання Вами цього виду статті. Запропонуйте назву статті. 
Лекція-дискусія 3. Структура наукових статей різних видів з методики навчання іноземних мов і культур. Функції наукової статті.

Презентація аспірантами виконаних самостійно практичних завдань. Обгрунтування аспірантами визначення видів обраних методичних статей. Пояснення аспірантів щодо вибраного виду статті для написання та ії̈ назви. Теоретичні питання для розгляду. Структура дослідницької статті, статтікороткого повідомлення, статті-відгуку і відповіді, оглядової статті. Дослідницька функція наукової статті. Презентаційна функція наукової статті. Оцінювальна функція наукової статті. Комунікативна функція наукової статті. Практичні завдання для самостійного позааудиторного опраџювання.

- Виберіть з науково-методичного журналу «Іноземні мови» за останні п’ять років по одній статті кожного з видів і визначіть їхню структуру і функцію. Підготуйте електронну презентацію у PowerPoint. Режим доступу: http://fl.knlu.edu.ua

- Запропонуйте структуру Вашої уявної оглядової статті.

Лекція-розгляд конкретної ситуації 4. Зміст і структура наукової статті у фахових виданнях України.

Презентація аспірантами виконаних самостійно практичних завдань.

Демонстрація з використанням презентації у PowerPoint підібраних статей різних видів (дослідницької статті, статті-короткого повідомлення, статтівідгуку і відповіді, оглядової статті) та опис їхньої структури та функції.

Опис і обгрунтування запропонованої аспірантами структури уявної оглядової статті.

Теоретичні питання для розгляду. Зміст статті: виклад проміжних або кінцевих результатів наукового дослідження; висвітлення конкретного окремого питання за темою дисертації чи наукового дослідження; Фіксація процесу наукового дослідження автора тощо. Структура статті: УДК, анотація, вступ, основна частина, завершальна частина, посилання на використані джерела (література). Практичне завдання для самостійного позааудиторного опраџюювання. 
- Подивіться відеолекцію «Як написати наукову статтю» і визначіть, що означає схема «MRCI Framework». Режим доступу https://www.youtube.com/watch?v=iEsk7N0spNI

- Визначіть структуру Вашої статті, обраного виду, яку Ви плануєте опублікувати у фаховому науковому виданні України. Підготуйтеся до іiі презентації та обгрунтування на наступній лекції.

Лекція-дискусія 5. Універсальна десяткова класифікація (УДК). Мета УДК та анотації наукової статті 3 методики навчання іноземних мов і культур та ключових слів.

Презентація аспірантами виконаних самостійно практичних завдань. Пояснення значення схеми «MRCI Framework» за переглянутою відеолекцією. Презентація-дискусія структур статей, підготовлених аспірантами.

Теоретичні питання для розгляду. Мета УДК і процедура ї̈ визначення. УДК онлайн. Вимоги до анотації наукової статті згідно з Міждержавним стандартом ГОСТ 7.9-95 (http://edumag.mrsu.ru/content/files/GOST_7.9-95.pdf) «Реферат i анотація. Загальні вимоги». Рекомендовані середній обсяг анотації (500 друкованих знаків) та елементи анотації відповідно до зазначеного стандарту (характеристика основної теми, визначення проблеми, конкретизація мети, опис результатів дослідження, виокремлення новизни у порівнянні 3 іншими роботами). Вимоги до характеру і кількості ключових слів (мінімум 5 позицій). Практичне завдання для самостійного позааудиторного опраиювання.

- Проаналізуйте елементи п’яти анотацій до статей з методики навчання іноземних мов і культур і ключових слів до них у різних наукових фахових виданнях України в галузі освіти.

- Укладіть анотацію та ключові слова до запланованої Вами до написання статті.

Лекція-бесіда 6. Вимоги до вступу, основної і завершальної частин статті з методики навчання іноземних мов і культур. Презентація аспірантами виконаних самостійно практичних завдань. Аналіз п’яти анотацій статей і ключових слів, обраних аспірантами. 
Демонстрація та обговорення укладених аспірантами анотацій статей і ключових слів.

Теоретичні питання для розгляду.

Складові вступу до наукової статті: постановка проблеми, аналіз останніх досліджень і публікацій; опис наукової гіпотези; пояснення передумов започаткування дослідження; зазначення мети та актуальності; перелік питань для розгляду тощо.

Складові основної частини статті: основний матеріал дослідження; власні наукові ідеї, виявлені закономірності; реалізовані методи дослідження; отримані результати тощо.

Складові завершальної частини статті: результати дослідження та їх значущість для теорії і практики методики навчання іноземних мов і культур; перспективи подальших досліджень з проблеми тощо.

Практичне завдання для самостійного позааудиторного опраџювання.

- Напишіть вступ до Вашої уявної статті.

- Підготуйте його п’ятихвилинну презентацію на наступній лекції.

Лекція-розгляд конкретної ситуації 7. Академічна доброчесність. Унікальність статті. Плагіат і самоплагіат.

Презентація аспірантами виконаних самостійно практичних завдань.

Розгляд підготовлених аспірантами вступів до запланованих статей.

Теоретичні питання для розгляду. Поняття «академічна доброчесність», «унікальність статті», «плагіат», «самоплагіат». Складові, норми та кодекс академічної доброчесності. Компетентності з академічної доброчесності. Форми проявів академічної недоброчесності (плагіат, самоплагіат, фабрикація, фальсифікація, обман тощо). Вимоги до унікальності статті з методики навчання іноземних мов і культур.

Перегляд і обговорення відеофільму «Як не попастися на плагіаті?» Режим доступу: https://www.youtube.com/watch?v=P6dbT3NuYOI Практичне завдання для самостійного позааудиторного опрачювання. 
- Подивіться фрагмент відеолекції «Етичні питання публікації результатів наукового дослідження».

Режим достуny: https://www.youtube.com/watch?v=Rxsz7TAZQZ4

- Перевірте на унікальність підготовлені Вами анотацію і вступ до запланованої статті за допомогою програми «Unicheck».

Режим доступу: https://ua.unicheck.com/

Лекція-дискусія 8. Редагування тексту наукової статті з методики навчання іноземних мов і культур.

Презентациія аспірантами виконаних самостійно практичних завдань.

Дискусія на тему «Проблеми етики наукових публікацій» за переглянутою відеолекцією.

Обговорення результатів перевірки анотацій і вступів до статей на унікальність. Теоретичні питання для розгляду. Уніфікація стилю формулювань і термінів. Перевірка наявності опису всіх завдань статті, заявлених у Вступі. Узгодження висновків статті зі змістом основної частини. Узгодження змісту Вступу зі змістом основної і завершальної частин. Перевірка дотримання технічних вимог до оформлення статті.

Практичне завдання для самостійного позааудиторного опращювання.

- Подивіться відеофільм «Editing: Things they don't tell you about what journal editors want.» і укладіть перелік наданих редактором рекомендацій щодо редагування наукової статті.

Режим доступу: https://www.youtube.com/watch?v=vLojaTRoBuc\&t=97s

- Відредагуйте фрагмент статті, який ви підготували, враховуючи прослухані рекомендації.

Лекція-розгляд конкретної ситуації 9. Вимоги до укладання та оформлення списку літератури з методики навчання іноземних мов і культур. Презентація аспірантами виконаних самостійно практичних завдань. Обговорення укладених переліків рекомендацій щодо редагування наукової статті.

Оцінювання відредагованих аспірантами фрагментів статей. 
Теоретичні питання для розгляду. Основні підходи до пошуку та укладання списку літератури з проблеми статті. Оформлення списку літератури згідно 3 чинним стандартом України (ДСТУ 8302:2015... 2015). Орієнтовні вимоги до оформлення рукописів (можливі розбіжності до оформлення статей у різних виданнях).

Практичне завдання для самостійного позааудиторного опращъювання.

- Подивіться відеозапис онлайн-семінару «Особливості оформлення літературних джерел до наукової статті».

Режим доступу: https://www.youtube.com/watch?v=8-GJpwcStPA\&t=72s

- Оформіть літературу до Вашої запланованої статті за опрацьованим стандартом.

Лекція-бесіда 10. Вибір наукового фахового видання України для опублікування підготовленої статті 3 методики навчання іноземних мов i культур. Категорії фахових видань. Вимоги до подання статті до видавництва. Презентація аспірантами виконаних самостійно практичних завдань. Демонстрація аспірантами оформленої згідно з чинним ДСТУ літератури. Теоретичні питання для розгляду. Умови зарахування публікації за темою дисертації (обгрунтованість отриманих наукових результатів відповідно до мети статті та висновків; наявність видання у переліку фахових видань України; опублікування не більше однієї статті в одному номері/випуску видання тощо. Умови зарахування статей, опублікованих у наукових періодичних виданнях інших держав з наукового напряму, за яким підготовлено дисертацію. Причини не зарахування опублікованих статей. Матеріали, які подаються до редакції (надрукований текст статті (факультативно); електронний варіант статті; відомості про автора (-ів) витяг з протоколу засідання кафедри/вченої ради 3 рекомендацією рукопису до друку та рецензію наукового керівника на подану статтю). Порядок формування Переліку наукових фахових видань України, затвердженого наказом МОН України від 15 січня 2018 року № 32 (Наказ МОН ... 2018). Реєстр наукових фахових видань України.

Практичне завдання для самостійного позааудиторного опрацуювання. 
- Знайдіть на сайті МОН України закладку «Реєстр наукових фахових видань України».

Режим доступу: https://mon.gov.ua/ua/nauka/nauka/atestaciya-kadriv-vishoyikvalifikaciyi/naukovi-fahovi-vidannya

- Випишіть: назви десяти видань 3 педагогіки та методики навчання іноземних мов; засновника або співзасновника цих видань; дату включення або внесення змін до цього видання; категорію видання (А чи Б).

- Подивіться відеолекцію «The Art of Scientific Publishing» і вирішіть, чи готові Ви до написання наукової статті.

Режим доступу: https://www.youtube.com/watch?v=ONdfTAOblJ8

Визначіться, до якого видання Ви будете подавати свою першу статтю. 